\title{
Pseudolingvistika kui folkloorinähtus
}

\begin{abstract}
Maarja Villandi
Teesid: Artiklis kirjeldatakse ebateaduslikke keelesuguluse teooriaid ning tuuakse välja nende tunnused ja tekkepõhjused. Seejärel antakse ülevaade Henrik Juhankatti, Arthur Gleye, Edgar Valter Saksa, Jüri Härmatare ja Oskar-Adolf Põldemaa loodud ebateaduslikest eesti keele suguluse teooriatest. Kõik autorid, kellest ükski ei ole keeleteadlane, omistavad eesti keelele (resp. läänemeresoome keeltele) tohutu tähtsuse kauges minevikus, mille kohta keeleandmed puuduvad. Samuti seostavad nad eesti keelt (resp. läänemeresoome) keeli vanade kultuurkeeltega (nt etruski). Teooriad on pälvinud palju kriitikat ja neid on lausa kahjulikeks peetud. Artikli autor jõuab kokkuvõttes seisukohale, et pseudolingvistilised teooriad ei pruugi olla kahjulikud, vaid neid tuleks käsitleda folkloorse ilminguna, mis väärib uurimist.
\end{abstract}

Märksõnad: folkloor, paraloogiline vorm, pseudolingvistika, rahvalingvistika

Käesolevas artiklis käsitletakse alates 1920. aastatest avaldatud pseudolingvistilisi teooriaid eesti keele suguluse alal. Teemat on suhteliselt vähe uuritud ja kirjandust pseudolingvistika kohta on vähe. Valikuni on viinud ka mõttekäik, et nii kaua kui on olemas olnud keeleteadus, on olemas olnud ka pseudolingvistika, mis ei lakka olemast ka edaspidi.

Teema haakub lisaks keeleteadusele (kus sellele on lähenetud valdavalt kriitiliselt, rakendades võrdlevale keeleteadusele kohandatud nõudeid) ka folkloristikaga, mis üha enam on hakanud anonüümselt levivate pärimustekstide asemel vaatlema konkreetsete autorite mitteteaduslikke seletus- ja staatusjutte (vt Kõiva \& Kuperjanov 2005: 201-202), mille abil antakse edasi arusaamu ja väärtushinnanguid, ning kultuuriantropoloogiaga, mis uurib muude kultuuriavalduste seas ka inimeste arusaamisi, veendumusi, uskumusi ja ettekujutusi. Keeleteadus kui üks kultuurispetsiifilisemaid teadusalasid kannab end saatvas pseudolingvistikas seega ka kultuurispetsiifilisi hoiakuid, millel on suhtumiste ja kultuurinähtuste koha pealt väärtus uurimisainesena. Mitmed autorid on 
pseudolingvistika uuringuid vaadelnud teadushariduse käsitlusalana (Martin 1994: 357; Good 2009).

Samas on ka seisukohti, mis näevad pseudolingvistikas, eelkõige harrastuslikus keeleuurimises ohtu just hariduse andmise valdkonnas. Harrastusliku keeleuurimise kohta kasutatakse terminit "rahvalingvistika" (folk linguistics) ja see termin on valdavalt kasutuses pejoratiivsena. Rahvalingvistika võib viidata ka mingile ideoloogiale ja natsionalistlikele vaadetele. Nii avaldab keeleteadlane Ray Jackendoff ettekandes "The Structure of Language: Why It Matters to Education" muret, et rahvalingvistikat kasutatakse laialt koolides. Ta peab seda ohtlikuks, sest rahvalingvistika on kantud uskumusest, et on olemas "hea" ja "halb" keelerääkimise viis ehk kes räägib vähemtuntud murret, räägib ebakorrektset keelt (Jackendoff 2003). Rahvalingvistikas on puudusi näinud teisedki autorid. Nii kirjutavad Nancy A. Niedzielski ja Dennis Richard Preston, et vastuargumentideks rahvalingvistika levitamisele on peale ebateaduslikkuse veel andmete lünklikkus ja keeleteaduslikult oluliste andmete kättesaamatus (Niedzielski \& Preston 2003: 3-7). Keeleteaduse ja pseudolingvistika vahel on vaja mõistagi vahet teha. Samas tuleb arvestada ka võimalusega, et mõnda teooriat ei saagi pidada kindlalt teaduslikuks või ebateaduslikuks, kuna selles sisalduvad väited on ebakonventsionaalsed ja nende paikapidavuse või paikapidamatuse tõestamine võib nõuda senitundmata ala uurimist või pöördumist muude teadusharude poole. See aga võib teooria avaldamise hetkel olla teadusringkonnale liialt ebamugav või aeganõudev ning seetõttu võidakse ebakonventsionaalne teooria kõrvale heita kui ebateaduslik. Ingliskeelses keeleteaduslikus kirjanduses on terminit pseudo-linguistics kasutatud paiguti ka ebakonventsionaalse keeleteaduse kohta (vt nt Robert Halli ([1977] 1987: 80 ja Paul M. Postali (Postal 2004: 322) kriitikat Noam Chomsky keeleteaduslike seisukohtade aadressil või soome-ugri keelepuu "raiuja" Kalevi Wiiki teooria kahtluse alla seadmist nii Soomes kui ka Eestis (Aikio \& Aikio 2002; Laaksoo 2000; Ehala 2005; Lõugas 1997 jt)).

Otseselt pseudolingvistika kohta leidub vähe kirjandust. Seda esineb üksikute artiklitena, milles pseudolingvistika mõistet seletatakse. Kirjutatud on küll pseudolingvistiliste teooriate autoritest, ent neid ei ole käsitletud niivõrd teadusliku diskursuse raames kuivõrd meediatekstides. Oma analüüsi aluseks võtan eelkõige Peeter Saari (2008) teaduse ja ebateaduse võrdluse. Samadele seisukohtadele olen tuginenud ka oma magistritöös (Villandi 2010).

Autorid, keda artiklis käsitletakse, on Henrik Juhankatti (kodanikunimega Treufeldt, 1873-?), Arthur Gleye (1867-1937), Edgar Valter Saks (1910-1984), Oskar-Adolf Põldemaa (1919-2005) ja Jüri Härmatare (1911-1989). Pseudolingvistiliste teooriate loojatel ei ole keeleteaduslikku haridust ja nad ei tegutse 
keeleteadlaste ringkonnas. Pseudolingvistikaks arvamisel olen lähtunud järgmistest seisukohtadest:

- pseudolingvistilised teooriad koosnevad isoleeritud hüpoteesidest;

- pseudolingvistilised teooriad lähtuvad ideoloogiast ja uskumustest, mitte samal alal läbi viidud teaduslikest uurimustest;

- pseudolingvistilised teooriad ei arvesta keelemuutusi ajas ja ruumis, vaid lähtuvad tänapäevastest sõnakujudest, mida võrreldakse tuhandete aastate taguste teiste keelekujudega.

Vaatlen marginaalselt ka pseudolingvistiliste teooriate tekkemehhanismi ja seda, milliste teadusalade kaudu on võimalik neile läheneda. Lisaks arutlen, kas ebateadusel on ka positiivne funktsioon, ja kui, siis milline ning milliste markerite poolest erinevad pseudolingvistilised teooriad ebakonventsionaalsetest keeleteaduslikest teooriatest nii ülesehituselt kui ka teadusliku ja hariva kasu poolest.

\section{Ebateadus kui teaduse paraloogiline vorm ja paralleelnähtus}

Kus esineb nähtusi, seal esineb ka nende samade nähtuste paraloogilisi vorme. Neid võib nimetada ka nähtuste interpretatsioonideks või versioonideks, mis on tekkinud nähtuse enda paraloogilise tõlgendamise kaudu. Ebateadus on tekkinud teaduse paraloogilise tõlgendamise kaudu, kusjuures teadust peetakse üldjoontes teatud piirangutest hoolimata tõsiseltvõetavaks nähtuseks, aga ebateadust ei peeta üldjuhul isegi tähelepanu väärivaks. Samas on ebateadus teaduse täiesti normaalne kõrvalnähtus, sest alati leidub väljaspool teatavat teadusharu tegutsevaid isikuid, kel tekib vajadus tõlgendada sedasama teadusharu omal viisil ja kes usuvad end olevat leidnud lahenduse küsimusele, mis teadusharusiseselt tegutsejatele tundub üha mõistatuslikum ja vajab üha edasist uurimist.

Tavapruugis ebateaduslikke teooriaid tõrjutakse ja kohati naeruvääristatakse, aga kuna nad on sama vanad kui teadus ise ja neid on alati leidunud, oleks vaja neid ka aktsepteerida. Aktsepteerimine ei tähenda siinkohal võrdsustamist teaduslike teooriatega, vaid nähtuse enese aktsepteerimist ja selle võtmist osana folkloorist.

Paljusid teisi seletusfolkloori alla kuuluvaid nähtusi, näiteks koha- ja tekkemuistendeid, ei peeta ju ebateaduslikeks teooriateks. Nii võib igasuguse ebateaduse võrdsustada muude muistenditega ja pidada seda folkloorinähtuseks, teatavaks seletusmuistendite rühmaks. 


\section{Pseudolingvistika}

Rahvusvahelistest keeleteaduse entsüklopeediatest ei käsitle sugugi kõik pseudolingvistika mõistet. 2006. aastal ilmunud Keith Browni peatoimetatud 14köiteline Encyclopedia of Language \& Linguistics ei sisalda seda märksõna, seda sõna ei sisaldu ka indeksis, küll aga on määratletud mõningaid pseudolingvistilisi mõisteid, nt glossolaalia (Brown 2006, 5: 95-97). Pseudolingvistikaga seotud mõistetest on samas entsüklopeedias dešifreerimata kiilkirjade peatüki all nimetatud ka Phaistose ketast (Brown 2006, 11: 42).

1994. aastal ilmunud kümneköitelises The Encyclopedia of Language and Linguistics'is (Asher \& Simpson 1994) on pseudolingvistikat (pseudolinguistics) defineerinud Vjatšeslav Ivanov (1994). Tema definitsiooni kohaselt tähendab pseudolingvistika keelega seotud ebauskusid, mida ei ole võimalik teaduslikult võrrelda saadaolevate andmetega. Pseudolingvistika on keeleteadusega, eriti keelte päritolu uurimisega seotud sama palju kui alkeemia keemiaga ja astroloogia astronoomiaga (Ivanov 1994: 3390). Ivanovi määratluse järgi kujutab pseudolingvistika endast olemasoleva keele sõnavormide päritolu üle spekuleerimist ilma võrdleva keeleteaduse tehnikaid valdamata. Üks pseudolingvistika suund oli stalinlik ja hitlerlik meelevaldne sideme loomine rassi ja keelelise identiteedi vahel ning teiseks suunaks 20 . sajandi teisel poolel levinud matemaatika ja/või loogika terminite abil konstrueeritud pseudolingvistilised teooriad, millel puudusid selged definitsioonid. Olenemata pseudolingvistikateooriate ideoloogilisest tagapõhjast iseloomustab neid kõiki keeleteaduslike meetodite väärkasutus (Ivanov 1994: 3390-3392).

Terminit pseudolingvistika on eesti keeles kasutanud Paul Ariste. Ta on andnud ka selle mõiste eestikeelse definitsiooni 1940. aasta Eesti Entsüklopeedia täiendusköites: "Ebakeeleteadus, näiline keeleteadus, mis ei arvesta keeleteaduses kehtivaid meetodeid, vaid püüab täiesti meelevaldselt võrrelda keeli omavahel ja teha neist võrdlustest teaduslikult lubamatuid järeldusi. Keeleteaduses on tähtsal kohal keele arenemise kronoloogiline külg; e. ühendab aga praegu sarnasena näivaid keelekujusid, sellest hoolimata, et nende ajaline vahe võib olla aastatuhandeid. Tähtsamad e-harrastajad Eestis on olnud K. A. Hermann, A. Gleye ja Mägi Kurdla.” (Ariste 1940: 210.)

Pseudolingvistikat on Ariste käsitlenud ka ajalehes Sirp ja Vasar 1980. aastal (Ariste 1980). Teise eestlasena on seda temaatikat käsitlenud Jaan Puhvel (1996) artiklis "Hitiidid eesti pseudoteaduses". Mõlema autori kõnealused kirjutised on selgelt kriitilised käesolevas artiklis vaatluse all olevate ebakeeleteadlaste suhtes, koguni iroonilised ega analüüsi nähtuse olemust, vaid lähenevad sellele võrdleva keeleteaduse mõõdupuuga. 


\section{Pseudolingvistiliste teooriate tunnused}

Toon välja nende keeleteooriate tunnused, mille alusel keeleteooria kvalifitseerub pseudolingvistiliseks. Nendel teooriatel on olemas kõik Peeter Saari (2008) loetletud tunnused, mis kehtivad igasuguse ebateaduse kohta üldse, aga eristatavad on ka pseudolingvistika kui ühe ebateaduse haru spetsiifilised tunnused. Pseudolingvistiliste teooriate tunnused on ideaalsete konstruktsioonide kasutamine, eelajaloolise aja käsitlemine, toetumine andmete puudumisele, selektiivsus, ajaliste mõõtmete ignoreerimine, ruumiliste mõõtmete ignoreerimine, keskendumine sõnale ja uuritava keele tõstmine pjedestaalile.

Ideaalsete konstruktsioonide kasutamine. Näiteks usutakse, et keel muutub igal ajal sama kiirusega ja samal määral, et keelemuutused alluvad teatud matemaatilisele valemile, samuti ollakse veendunud ühise ürgkeele olemasolus, millest on välja arenenud kõik tänapäeva keeled. Sellise teooria näiteks on päikesekeele teooria. Selles artiklis vaadeldavatest ebakeeleteadlastest on ideaalset konstruktsiooni kasutanud Henrik Juhankatti nn ühise ürgkeele hüpoteesi kujul, milles ta omistab väga kindlaid tähendusi häälikutele ja silpidele.

Ajaliste mõõtmete ignoreerimine. Pseudolingvistikas võetakse aluseks uuritava keele tänapäevane sõnakuju ja mõne väljasurnud keele sõnakuju. Kui need kokku langevad, tehakse automaatselt järeldus, et tegu on samade sõnadega, mis viib kergesti ka järeldusele sugulusest. Ehedaks näiteks sellest võttest on Oskar-Adolf Põldemaa, kes on loonud seoseid hääbunud etruski keele ja tänapäevase eesti keele vahel, eeldades, et need on olnud sama tagapõhjaga ja eesti keel oli enam-vähem oma praegusel kujul olemas juba tuhandeid aastaid tagasi.

Ruumiliste mõõtmete ignoreerimine. Asetatakse sugulusse geograafiliselt väga kauged keeled. Nii on Henrik Juhankatti seadnud omavahel sugulusse eesti ja jaapani keele.

Eelajaloolise aja käsitlemine. Pseudolingvistilised teooriad käsitlevad kauget ja kontrollimatut minevikku, mille kohta keeleandmed on fragmentaarsed või puuduvad täielikult. Edgar Valter Saks on tuginenud eelajaloolisele Euroopale.

Toetumine andmete puudumisele. Kuna pseudolingvistilised teooriad käsitlevad kauget ja kontrollimatut minevikku, ei toetuta niivõrd olemasolevatele ja kontrollitavatele andmetele, kuivõrd hoopis andmete puudumisele. Andmete puudumisele toetuvad sisuliselt kõik käesolevas artiklis käsitletud pseudolingvistiliste teooriate loojad. Sellel põhimõttel kasutab Arthur Gleye ära asjaolu, et teatud muistsete rahvaste keele kohta puudub ühene seisukoht ja andmed sellest keelest on fragmentaarsed. Nii on võimalik panna fragmendid 
kokku sellisel viisil, et moodustuks sobiv mosaiik. Ka Edgar Valter Saks leiab piisavalt põhjust pidada ca 4000 aasta tagust Euroopat Esto-Europaks, sest usaldusväärseid keeleandmeid ei ole ja nii on tal võimalus endale sobival viisil seda nn lünka täita.

Selektiivsus. Kui olemasolevaid ja kontrollitavaid andmeid kasutatakse, tehakse seda selektiivselt, st valitakse vaid teooriat toetavad andmed. Selektiivsuse põhimõttel on näiteks Edgar Valter Saks võtnud kasutusele Euroopa kohanimed ja loonud seoseid tänapäeva eestikeelsete sõnadega, sest nii on tal kõige lihtsam toetada oma uskumust kunagisest Esto-Europast.

Keskendumine sõnale. Keelesuguluse selgitamisel ei arvestata keeles muid nähtusi peale sõnade. Sõnale keskendumine on pseudolingvistika puhul väga tüüpiline. Üks markantsemaid nn sugulassõnade loendeid pärineb Henrik Juhankattilt, kes on leidnud hulgaliselt sarnaseid sõnu eesti ja jaapani keeles.

Uuritava keele tõstmine pjedestaalile. Keelt seostatakse vanade kultuurkeeltega (sumeri, etruski) ning sellele omistatakse tohutu tähtsus kadunud maailmas. Veel enam, vana kultuurkeel võrdsustataksegi uuritava keelega. Gleye võrdsustas eesti keele vanade kultuurkeeltega, nt etruski keelega. Edgar Valter Saks jällegi "kattis" eestlastega kogu muistse Euroopa.

Pseudolingvistilised keeleteooriad on vajalikud näiteks väikerahvaste eneseteadvuse tõstmiseks ja säilitamiseks. Et üldtunnustatud, teaduslikud keeleteooriad pidevalt kinnitavad nende väiksust ja ebaprestiižikust, vajatakse vastupidiseid kinnitusi. Kuna pseudolingvistilised seisukohad ei ole faktidega kinnitatavad ning seega ei saa nende paikapidavust ka faktiteadmiste alusel teada, jääb üle vaid neid uskuda. Usutakse sageli mitte seda, mis vastab tõele, vaid mida on turvaline uskuda. Miks uskuda seda, et me polnud muud kui olematu staatusega korilased, kui on võimalik uskuda, et me olime väikseid hõime kokkuliitev kaupmeesrahvas, kes kujundas kogu Põhja-Euroopa keeleruumi? Kristi Kukk võtab olukorra kokku järgmiselt: "Oma identiteeti otsiva väikerahva jaoks ei saanud olla paremat uudist, kui põlvnevus ühest vanimast kultuurkeelest maailmas [---]" (Kukk 2005: 77).

Neid teooriaid on enamasti loonud mittekeeleteadlased, isikud, kellele eneseteadvus on olulisem kui teadus ja faktiliselt kinnitatavad materjalid. Nn asjaarmastajatel on paremad eeldused luua pseudolingvistilisi teooriaid, sest neil puudub segav teaduslik tunnetus. Keeleteadusliku tausta puudumine võimaldab ignoreerida seda, mida üldtunnustatud keeleteooriates poleks võimalik ignoreerida.

Pseudolingvistilisi keeleteooriaid ei leidu aga ainult väikerahvastel. Mõnel suurrahval (nt päikesekeelte teooria türklastel) on see samuti olemas, aga mitte enam oma suuruse tõestamiseks kontrollimatult kauges minevikus, vaid teiste keelte üle domineerimise kinnitamiseks. Nii usub sellise teooria looja, et tema 
emakeel on maailma vanim või vähemalt sellele kõige lähedasem keel. Üheks näiteks võib tuua pan-aaria liikumise, mis oli katse tõestada nn aaria rassi ehk valge rassi ülimuslikkust teiste suhtes. Siinkohal võib veel mainida marrismi, mis sai oma nime Nõukogude teoreetiku Nikolai Marri (1865-1934) järgi, kes nimetas oma nelja algupärase silbi teooriat "uueks keeledoktriiniks" (Ivanov 1994: 3391). Marri nn jafeetiline teooria eiras igasuguseid teaduslikke fakte, mis Marrile kui teooria loojale meeltmööda ei olnud. Ta esindas radikaalset ideed, et keel on klassipõhine ja antud ühiskonna struktuur määrab mitte ainult keele sotsiaalse kihistumise, vaid ka tema struktuuri ja tüpoloogilised jooned (Lähteenmäki 2010: 35-36).

Kuna keskendun eesti keele sugulust käsitlevatele ebateaduslikele teooriatele, kõnelen nende tekkimisest eneseteadvuse tõstmise eesmärgil. Kontrollitavas ajaloos on eestlaste majanduslik-sotsiaalne staatus olnud madal ja peaaegu kogu aeg on Eestis kehtinud mõne suurema rahva ülemvõim. Vajaduse eneseteadvuse tõstmiseks on loonud saksa ülemvõimu ajast pärit arusaam, et eesti keel on köögikeel, mitte kultuurkeel. Selline arusaam kaasneb mõne teise rahva ülemvõimu ja kõrgema staatusega peaaegu alati. Mõistes, et lähem ajalugu kõrget staatust ei võimalda, otsivad pseudolingvistiliste teooriate loojad teadlikult või ebateadlikult seda kaugemast minevikust, mida ei saa kontrollida või mille kohta leiduvad vaid lünklikud tõendid, mida on võimalik tõlgendada meelepärasel viisil. Eestlaste rahvuslikku alaväärsuskompleksi on käsitlenud taani päritolu Eesti ja Saksa ajaloolane Paul Johansen. Ta seletab alaväärsustunde teket rõhutud talupojaseisusega aadlivõimu piirkonnas. Sajandite vältel määras seisuse rahvuslik kuuluvus, st sakslased olid ülemas, eestlased alamas seisuses. Nii pidi sotsiaalsele alaväärsustundele lisanduv natsionaalne motiiv alaväärsuskompleksi veelgi tugevdama (Johansen 1989: 1502).

Samuti on pseudolingvistilised teooriad vajalikud enese identiteedi leidmiseks kättesaadavate vahendite abil. Selleks otsitakse juuri. Pinnase selleks loob seostamatus naaberrahvastega, lähemate analoogide puudumine või asjaolu, et tõestatud sugulus ei rahulda teooria loojat.

\section{Pseudolingvistilised teooriad eesti keele suguluse alal}

Käesolevas kirjutises vaadeldakse 20. sajandil avaldatud Henrik Juhankatti, Arthur Gleye, Edgar Valter Saksa, Jüri Härmatare ja Oskar-Adolf Põldemaa pseudolingvistilisi teooriaid eesti keele suguluse alal. Nende teooriate tutvustamiseks on kasutatud Edgar Valter Saksa raamatut Esto-Europa: A Treatise on the Finno-Ugric Primary Civilization in Europe ja Oskar-Adolf Põldemaa üllitist Muinaskiirkiri kõneleb eesti keeles. Esimeseks arvestatavaks pseudolingvistilise 
eesti keele suguluse teooria loojaks võib pidada Karl August Hermanni, kes avaldas 1896. aastal raamatu Sumeri-akkadlased, milles kuulutati sumerid kiilkirjade tõlgenduse alusel eestlaste sugulasteks. See teooria jääb siinkohal pikemalt käsitlemata, sest see jääb vaatlusalusest ajaraamist välja.

\section{Henrik Juhankatti teooria}

Kõige varasem käesolevas töös käsitletav pseudoteaduslik teooria pärineb Tõrva kaupmehelt Henrik Juhankattilt, kes avaldas 1927. aastal oma kodulinnas raamatu Inimkonna keelte tekkimine ja arenemine, milles idealiseerib läänemeresoome keeli kui inimkonna ürgkeele ainet kõige paremini säilitanud keeli. Viis aastat hiljem (1932) andis ta sealsamas välja ka viis numbrit okultistliku sisuga ajakirja Aovalgel (Kannukene 2008: 59-62). Ka jõudis ta saada koos teise Tõrva mehe Henrik Annikuga igiliikuri patendi (L-E 1928).

Juhankatti arendab edasi oma eelkäija Jüri Truusmani mõttekäike ja kritiseerib keeleteaduslikus maailmas tunnustatud häälikumuutuste ja laensõnade teooriat. Eriti kriitiliselt suhtub ta oma kaasaegsete klassikute Jaan Jõgeveri ja Andrus Saareste õpetusse. Ta ei pea loogiliseks häälikumuutusi (kuidas läti sirgs'ist eesti hobune ja härg saada võis?) ega võimalikuks klassikute poolt leitud hulgal laensõnu, sest nii vanas keeles, nagu eesti (resp. soome sugu) keel, ei saanud ju puududa kõige algelisemadki kultuursõnad. Ta kritiseerib tollast keeleteaduse suunda, mis tegeles laensõnade otsimisega. Klassikute kritiseerimise põhjuseks toob ta just teaduse pideva muutumise, mida klassikud arvesse ei võta, sest “mõni sada aastat ainult veel tagasi, valitses Euroopa arstiteaduses kindel arvamine, et seep on parim abinõu paljude haiguste vastu [---]" (Juhankatti 1927: 18).

Nendest mõtetest lähtudes avaldab ta oma teooria, mida ta peab eesti rahva suure mineviku ja kultuuri tõenduseks. Alustuseks kirjeldab ta omaloodud häälikulugu, milles seletab oma nägemust häälikute tekkimisest kronoloogilises järjekorras. Nii usub ta, et kõige esimene häälik, mida inimene oma mõtete väljendamiseks kasutas oli $n$, sest inimese kõige algelisemad tunded olid kas "hea" või "halb”, "jaa” või "ei”. Tal on loodud ka terve häälikute tähendussüsteem ja ta usub, et kõik häälikud tähistavad mingit spetsiifilist olukorda ja väljendavad mingeid kindlaid mõisteid. Nii on ta loonud teooria, et häälik $a$ tähendab algust ja alust ja võib väljendada nelja mõistet: vesi, üla, ühinemine, alus-algus. (Juhankatti 1927: 54.)

Edasi toob ta välja omaloodud silpide tähendussüsteemi, mille põhjal järeldab, et Õhtumaade keeltest on soome ja eesti keel kõige paremini säilitanud "ühise ürgkeele" ainet. Ta usub, et läänemeresoome ja keldi keeled on kauges 
minevikus seisnud üksteisele väga lähedal ning keldi keeled on mänginud suurt rolli ladina keele kujunemisel. Edasi toob ta sõnaloendeid, tõendamaks eesti keele sugulust ladina ja jaapani keelega. Illustreerimiseks toob ta näiteid ladina (variare 'varjundama, muutma', studere 'tundma õppima, tudeerima', prisca 'priske, muistne' - Juhankatti 1927: 103-104) ja jaapani keelest (juu 'õhtu, öö'; sureta 'maha matma', jameru 'jääma'; gendžiru 'kängu jääma'; soodainin 'saadik' - Juhankatti 1927: 116).

Nende näidete põhjal jõuab ta veendumusele, et tegemist on sugulusega, mida ei tunnistata, sest see ulatub väga kaugesse minevikku. Nii on ta veendunud, et jaapani, sumeri, ladina, Kesk-Ameerika pärismaalaste ja muistne egiptuse keel on omavahel suguluses. Neid sugulussidemeid aga ei saavat seletada ajalugu, sest see on noorem nendest keeltest ja seletust võibki leida ainult nendest keeltest (Juhankatti 1927: 125).

\section{Arthur Gleye teooria}

1937. aastal Tallinnas ilmunud teoses Die Wiedergeburt der westfinnischen Geisteskultur käsitleb Arthur Gleye muistsete Lõuna-Euroopa rahvaste päritolu, üritades neile lahendust otsida läänemeresoome keeltest. Tuginedes uskumusele, et kreeka mütoloogias tuntud Hüperborea elanikud olid läänemeresoomlased, peab ta võimalikeks muistseteks läänemeresoome rahvasteks näiteks liguure ja pelasge, kelle keelest andmed puuduvad, kuid mida Gleye usub edasi elavat muistsetes kohanimedes.

Liguuride hõimunime seletab ta järgmiselt. Itaalikutel esines võõrapäraseid diftonge, nagu iu : ui, mis kreekapärase häälduse läbi redutseerusid i-ks. Liguuriat tunti luikedemaana. Siinkohal pakub ta välja foneetilise võrdluse: a) eesti luikama, liugama 'abgleiten'; b) eesti luik, luige 'Schwan' (Gleye 1937: 35).

Sama tüve peab Gleye piisavalt produktiivseks, et pakkuda seda ka Lusitaania nime tüveks. Siia lisab ta järgmise võrdluse: eesti liug 'Gleiten', liuga 'abschüssig', liuguma : luiguma 'gleiten', liusk (gen. liuzu) 'schräg, abschüssig' (liusku laskma = liugu laskma), liusk (gen liuza) 'Schlittschuh', liuzata 'gleiten'; soome liukua 'gleiten', luistaa 'gleiten', (LUIG, LIUG : LUIST) = luisu 'abschüssig'. Nende võrdluste alusel tekib tal järeldus, et Liguuria ja Lusitaania nimed viitavad Lääne-Euroopa mereäärsetele läänemeresoome päritolu elanikele (Gleye 1937: 51).

Ka Kreeka muistsete asukate pelasgide nimetus põhinevat sõnal põllurahvas. Lisades hulga samalaadseid näiteid, teeb ta järelduse, et pelasgid olid etnoloogilises mõistes muistse Euroopa läänemeresoome keelt kõnelevad rahvad (Gleye 1937: 58-59). Üks kuulsamaid poleemikat põhjustanud Gleye näiteid 
on tema katse seletada Vana-Kreeka tulejumala Hephaistose nime päritolu. Võimalik, et saksa kirjapildi Häphaistos tõttu seostub see Gleyele järgmiste sõnadega: eesti-soome sõnaga hä̈̈, millele lisandub paistus (paistoa). Teine samaväärne etümoloogia on nime Oinomaos kohta, mida ta usub koosnevat eestikeelsetest sõnadest Oina-mao (Gleye 1937: 9.)

Kogu Gleye teooriat läbib kinnisidee, et muistne Euroopa kõneles läänemeresoome keeli ja ta omistab läänemeresoome keeltele müütilise tähtsuse. Ta otsib järeldusi välistest sarnasustest, püüdes leida läänemeresoome sõnu igast võimalikust vanast nimest või tekstist ning loob automaatse seose tänapäevase läänemeresoome sõnakujuga. Suuresti tugineb ta andmete puudumisele ja lünklikkusele nii vana aja kohta kui tema käsitleb. Olemasolevaid andmeid kasutab järjekindlalt oma oletuste kinnitamiseks.

\section{Edgar Valter Saksa teooria}

Gleye mõttekäiku jätkas Edgar Valter Saks 1966. aastal avaldatud teoses EstoEuropa: A Treatise On The Finno-Ugric Primary Civilization in Europe, käsitledes Euroopa kohanimesid, sidudes neid eesti (resp. soome-ugri) sõnatüvedega. Oletusele, et need kohanimed, mille kuju sarnaneb mõnele tänapäevasele eesti sõnatüvele, tulenevadki eesti (resp. soome-ugri) sõnatüvedest, otsib ta kinnitust Kunda kultuurist ja eelajaloolisest ajast, mille kohta keeleandmed puuduvad. Kohanimesid klassifitseerib ta jõgikondade ja elatusalade kaupa. Laialdast ala, kus autor on niisuguseid kohanimesid avastanud, nimetab ta Esto-Europaks. Teoses on välja toodud kohanimede loendid üksikasjaliste seletustega ja lisatud on ka kaks kaarti nn Esto-Europa idapoolse ja läänepoolse ala kohta. Autor ei piirdu üksnes kohanimedega, vaid seostab eesti (resp. soome-ugri) sõnatüvesid ka hõimunimedega (nt vandaalid).

Saks oletab, et suuremat osa Euroopast asustasid enne indoeuroopa hõimude (resp. keltide, germaanlaste ja slaavlaste) sisserännet soomeugrilased. Seda peab ta kehtivaks eelajaloolise aja kohta, mille materiaalse kultuuri kohta on võimalik andmeid saada, aga keele kohta tõenäoliselt mitte. Ent Saks peab eelajalooliste keeleandmete saamist võimalikuks, sest "kohanimed on vaatamata arvukatele elanikkonnavahetustele väga püsivad ja nad on säilitanud oma algupärase vormi ja juured, näiteks 60\% Gallia kohanimedest, mille Caesar pani kirja aastail 56-51 eKr, reedavad võimalikku soome-ugri päritolu, vastavad soome-ugri tüüpilisematele kohanimedele ja seega ei vaja põhjalikumat uurimist" (Saks 1966: 18). Tema omaloodud etümoloogiad põhinevad vanadel kroonikatel, kus on analüüsitavaid kohanimesid mainitud tänapäevasest teistsugusel kujul. Ta on välja valinud nimekujud, mis sarnanevad mõnele 
tänapäevasele eesti (resp. soome-ugri) sõnale ja toetavad seega tema oletusi. Tegu ei ole sageli väikeste, tähtsusetute kohanimedega, vaid tänapäeva Euroopas määrava tähtsusega kohanimedega. Mõnikord muutuvad Saksa pilgu läbi soome-ugri tüvelisteks ka riikide nimetused.

Üks tema etümoloogiate markantsemaid näiteid on katse viia soome-ugri tüvele Iirimaa nimetus (Éire). Seletust alustab ta sellest, et võtab aluseks Helmoldi Slaavlaste kroonikas (Helmoldi Presbyteri Chronica Slavorumis; 1167-1168 ja 1172) mainitud jõenime Hyrundo (AD 1137 Suale, tänapäeval Schwale) ja seostab seda Taani hindamise raamatus (Liber Census Daniae, ca 1241. a) mainitud Eesti kohanimekujudega Üheks looduse eripära kirjeldavaks etümoloogiaks toob Saks ka Pariisi ajaloolise nime Lutetia, mis on Strabọni Euroopa kaardil kirjas kujul Loukotokian ja Ptolemaiosel Leukotekia ning paljudes vanades ülestähendustes Luteci, Lutetia, Lutecia, Lutica, Lu(o)cetia. Indoeuroopa keeleteadlased peavad seda pärinevaks ladina sõnast lutun 'muda, pori, savi' või keldi sõnast lutuhezi 'ehitis keset vett', 'Lucotiose eluase', aga Saks seostab seda soome sõnaga luoto 'väike saar jões, järves või meres' ja mütoloogilise paiga nimega Luotola Kalevalas, kusjuures on luote 'metsata ohverdussaar'. Siia lisab ta eesti sõnad lood, gen loou, loot, gen loodu 'väike metsata tasane saar, laid'. Kuna Caesari kirjapanekute järgi asus Pariis väiksel saarel, tekib Saksal järeldus, et Lutetia soome-ugri päritolu on tõenäolisem kui indoeuroopa päritolu, seda enam, et saared olid soomeugrilaste silmis seotud nõidusekultusega. Samuti ei tuntud ladinakeelses kirjapildis täishäälikuühendeid, seega on Lutetia kuju täiesti ootuspärane (Saks 1966: 141).

\section{Jüri Härmatare teooria}

Kanadas elanud, kuid Eestis sündinud Jüri Härmatare (sünninimega Georg Helmut Hermburg, 1911-1989) ei olnud samuti keeleteadlane. Temast on siinkirjutajale teada vaid asjaolu, et ta lõpetas 1939. aastal Tartu Ülikooli õigusteaduskonna diplomitööga Maakonna omahaldus ning oli eksiilis seotud kirikuga ja tegeles arheoloogiaga, mis nähtavasti viis ta sumeri sugulaste otsinguile.

Härmatare on Kanadas andnud välja raamatu Sumeri kilde. Raamatu alguses nimetab ta läänemeresoome keelte Uurali päritolu teooriat savijalgadel seisvaks ja spekulatiivseks, heites ette põhinemist ainult vähestel laensõnadel uurali-altai keeltest (Härmatare 1976: 7). Selle asemele pakub ta oma isiklikku teooriat, mis põhinevat arheoloogilistel väljakaevamistel Mesopotaamias. Väljakaevamised on andnud palju kirjalikke materjale kiilkirjade näol ja raamat keskendubki kiilkirja uurimustele. Härmatare peab kiilkirju Sumeri riigi avastamise põhialuseks. Raamatu on ta kirjutanud oma viieteistaastase 
arheoloogilise uurimistöö põhjal ning põhiliselt tutvustab ta Sumeri ja selle naaberalade kultuure, aga teeb juttu ka eesti ja sumeri keele seostest.

Oma teoses viib ta sumeri keele leiud kokku tänapäevase eesti keelega ning väidab täie tõsidusega, et eesti keelt ei tuleks otsida üksnes Läänemere ümbrusest, vaid palju kaugemalt, Vatikani muuseumist. Härmatare on toonud hüpoteetilise eesti keele esinemuse kohta järgmisi näiteid: sumerikeelne tekst 2500 eKr: MUL AN-TA SUR-RA SI-NUL NU-TA; hetiidi tekst (hieroglüüfiline) Anatoolia Kõrgmaalt, praegusest Türgist 1500 eKr: MA-H-LA PU-U (eriti ounaja viinamarjamahl); vanapärsia tekst 500 a eKr: VA-SA-RA KÄ-E-LA, PA-LUVA SA-NA A-NNA (kuninga palvus jumala poole). Peatükis Pärsia ajastu kohta toob Härmatare näite arheoloog Ernst Herzfeldi leitud kuningas Dariuse kivist uksekäepidemest, millel oleva kirja on ta dešifreerinud järgmiselt: Daaravahusa majaukse kaasa käina, kärata, esitades küsimuse: kuidas eesti keel Dariuse uksenupule sai (Härmatare 1976: 86).

Lõpuks asub Härmatare oma teooriale tõestust otsima etnograafilistest mustritest, tuues nn tõestuseks, et kaheksaharulise tähe motiiv Tarvastu ninarätikul on sarnane Halafi ja Siyalki tähtedele. Nii etnograafiliste mustrite kui ka kohanimede puhul toetub Härmatare püsiva iseloomu aspektile, nagu seda on teinud Edgar Valter Saks. Kusjuures oma raamatu kokkuvõttes rõhutab Härmatare, et on kõiki materjale käsitlenud objektiivselt ja hoidunud igasugusest rahvuslikust sentimentaalsusest.

\section{Oskar-Adolf Põldemaa teooria}

Oskar-Adolf Põldemaa oli seikleja nii elus kui ka teaduses, aga ka fantaasiates. Teada on, et ta sündis Saaremaal Valjala kihelkonnas taluperes ja hakkas pärast algkooli lõpetamist 1934. aastal merd sõitma. Oma sõnul jõudnud ta ka Hispaania kodusõjas vabariiklaste poolel võidelda ja Inglismaal Leedsi mereväekoolis allveelaeva mehaanikuks õppida, kuid selle kohta pole mingeid tõendeid. Küll aga õnnestus tal Teise maailmasõja ajal võidelda nii Vene kui ka Saksa poolel ning sõja järel Siberis karistust kanda. Oma töömehepõlve veetis ta pärast vabanemist samuti Siberis: Vladivostokis allveelaevade mootoreid remontides ja Magadanis elektrijaama turbiine monteerides. Ta oli eesrindlik töömees, aga ka Magadani oblasti poksitšempion. Eestisse Saaremaale naasis ta 1993. aastal ja just siin arendas ta ka oma pseudolingvistilist teooriat ning avaldas sellekohase trükise Muinaskiirkiri kõneleb eesti keeles (Pesti 2009a, 2009b). Oskar-Adolf Põldemaa teooria viib eesti keele tagasi muinaskiirkirjale, mille Itaalia arheoloogid leidsid Saavimaa pealinna Maariba (Ma'rib) veehoidla lähedalt ja mille vanuseks on pakutud viis tuhat aastat. See on silpkiri ehk 
selline kiri, kus üks täht märgib silpi. Selles silpkirjas näeb Põldemaa "puhast Saaremaa ja Põhja-Eesti keelt, mida mõistavad veel seitsmekümne aastased". Ta on uskumusel, et veel enne Nõukogude Liidu okupatsiooni räägiti Eestis kahekordset keelt: esiteks vana eesti keelt ja siis veel sellist, kus pandi igale sõnale juurde praeguse eesti keele sõnad. Arusaamise hõlbustamiseks pakub ta oma raamatus trükitud praeguse eesti keele sõnu ja väikeste tähtedega kirjutatud vana keele sõnu. Siinkohal võib välja tuua stiilinäite.

\section{VEESEADUS}

Loeme nü̈̈d kaljuseinalt korraldust põlluharijatele, mis anti neile viis tuhat aastat tagasi.

Üleval vasakul nurgas on silpkirjas kirjutatud (lugeda tuleb vasakult paremale) nii:

1) Ta ka haa PANEB ETTE ju pea nii KINDLALT TEILE

2) Peab hakkama see see ju MIS ÜLEVAL pea eks on nii VAATA KIRJUTATUD pea hakka HAKKAB

3) Nii ju on nii TEIE siin gijo vahi tea ära on nii OMATE VEE TEADMA PEAB SELGELT TEIE OMA KUUD

4) Pea VAATA pea UUEL tea ÖÖL need TEIE kuu KUUD See ju on nii kuu see ÜLEVAL TAEVAS

5) On nii ära SELGE see TAEVAS on nii TEILE NÜÜD pea hakka see ju kuu PEA HAKKAB ÜLEVAL KUU PAISTMA

Põldemaa tõlgendused põhinevad ideaalkonstruktsioonidel ja katsel ühendada muinaskiirkirja automaatselt eesti keelega. Ta usub, et muinaskiirkirjas oli iga märgi taga konkreetne eestikeelne sõna ja on konstrueerinud terveid lauseid. Nii on tulemuseks võrdlemisi piiratud sõnavaraga ennast kordav tekst.

\section{Pseudokeeleteaduse retseptsioonist}

Keeleteadlased reageerivad pseudokeeleteaduslikele teooriatele selgelt negatiivselt, sest ratsionaalsesse keeleteaduslikku diskursusse selline harrastusteadus ei mahu. Muus kontekstis võib aga eituse ja iroonia kõrval kohata ka suhtumist, mida võib nimetada huviks ebatavalise vastu. See on kõige sarnasem ja kohati ka kattuv ebateaduse folkloristliku retseptsiooniga. Seetõttu pööran põhitähelepanu just sellistele seisukohtadele.

Väikelinnas Tõrvas elava ja tegutseva isemõtleja Juhankatti teooriatele keeleteadlaste seas vastukaja ei tekkinud. Küll aga tutvustas J. Ultra 1928. aastal ajalehe Lõuna-Eesti 14. jaanuari numbris tema teost pealkirja all "Ülihuvitav raamat. Väga huvitavad väited H. Treufeldt'ilt" sõnadega: "Raamat on kirju- 
tatud huvitavalt, innuga loeb teda ka see, kellel keeleteadusest aimugi pole. Muidugi tuleb ära oodata raamatu kohta asjatundlik arvustus. Kuid igatahes on see ülihuvitav raamat, mis laialist tähelepanu peaks äratama” (Ultra 1928).

Ajaloolane ja ajakirjanik Juhan Libe (1904-1947) mainib teda "Ülevaates meie ajalookirjandusest läinud (1927.) aastal" siiski pigem ebaõnnestujana: "[---] oma kvantitatiivselt kaaluvamas ulatuses on just kõige enam end patriootiliseks tembeldavad asjaharrastajad ebaõnnestunud, nii et näilikud uued ameerikad on ikka jälle osutunud kui mitte hallutsinatoorseiks fantaasiakujutelmadeks, siis lihtsalt illusoorseiks suurestisteks, mis ka rahvusideoloogiliseltki ei suuda täita neid tekitavaid nõudlusi. Ei saa salata, et selle tendentsi tagakihutajaks on olnud oma põhiolemuselt võrdlemisi terve - ja tõttki riivav - instinkt, aga et see kõverpeeglilise karikatuurilme on võtnud - läinud aastal näit. A[leksander] Põrk'i "Eesti ajalugu I (ja II)" või H. Juhankatti "Inimkonna keelte tekkimise ja arenemise" kujul - ei ole põhjustatud niipalju seda suunavate tarvete eneste mitteolemasolemisest kui nende valestiarusaamisest ja teostamisvõimude ignorantsist" (Libe 1928).

Tänapäeval meenutatakse teda üksnes kurioosumite hulgas, näiteks Pekka Erelt (1999) nimetab teda Mägi Kurdla, Edgar V. Saksa ja isegi Karl August Hermanni kõrval üheks Eesti teaduse Toslemiks, viidates Romulus Tiituse pilava "Sugukonna-uurimuse" sellenimelisele tegelasele.

Arthur Gleye vastu polnud arvustajad algusest peale sõbralikud, v.a Mägi Kurdla oma ebateaduslikus raamatus. Paul Ariste on tema teooria suhtes sarkastiline ja tunneb piinlikkust raamatu Die Wiedergeburt der westfinnischen Geisteskultur riigi kulul väljaandmise pärast (Ariste 1937). Ka keeleteadlane Jaan Puhvel on sarkastiline, sedastades: “[---] piinlik teos, pühendatud Pätsile ja trükitud viimase armulikkusest Eesti Vabariigi kulu ja kirjadega" (Puhvel 1996).

Ometi pole tedagi unustatud. Para-webi foorumis võtab kasutaja Kulfing tema teooria teema "Aestid" all veel 14. jaanuaril 2008 üles (kirjaviis muutmata): "1937 aastal väitis ka professor Arthur Gleye, et piktid olid soomesugu merd sõitev rahvas Britannias. Seda juttu lugedes tahaks hüüda, puhas jama! Jama oleks siis, kui see oleks ainus väide. Lisagem siia Tacituse kirjutis" (Aesti 2007-2008).

Edgar V. Saks kui viljakas kirjutaja on mõistagi eelnevalt käsitletud pseudolingvistika teooriate loojatest tuntum, tõsi, eelkõige pseudoajaloolase ja kirjanikuna. 1920.-1930. aastatel avaldas ta Tartus neli romaani, neist tuntuima, Vene-Liivi sõda käsitleva Hannibali rahva ümbertöötatuna ka 1970. aastal Torontos (EKRL 1995: 502). Ent hoopis rohkem on tema sulest "raamatuina ilmunud rahvuspoliitilisi tendeeritud uurimusi soomeugrilaste ja eesti eelajaloo kohta" (Oja 1995: 502). Romaanidega samasse ilmumisaega 
jääb Ernst Enno üliõpilasaastad Korp! "Vironia” arhiivi valgusel (1935). Lisaks käesolevas uurimuses käsitletavale Esto-Europale kuuluvad Saksa (pseudo) teaduslikku bibliograafiasse veel 1960. aastal avaldatud Aestii, An Analysis of an Ancient European Civilization (Studies in the Ur-European History 1), Eesti soost vasallkond taaniaegsel Virumaal. Jüriöö mäss: Revideerivaid seisukohti ürikute valgusel (1971), Commentaries on the Liber Census Daniae: Studies in Mediaeval European History (1974), Saxi-Saxa-Sax-Saks: Nimikond ja suguselts. Genealoogiline uurimus (1979) ja The Estonian Vikings (1981) (EKRL 1995: 502). Viimane neist on tõlgitud eesti keelde ja ilmunud pealkirja all Eesti viikingid koguni kahes trükis (2003 ja 2005). Vaatamata sellele, et arvamusliidri staatuses arvustaja Andrei Hvostov märgib Eesti viikingite ilmumise puhul: "Oleks visiooni esmatrüki aastaarvuks 1881, võiks seda isegi täie rinnaga nautida. Paraku trükiti Edgar V. Saksa nägemus 1981. aastal Cardiffis. Seega pole tegemist mälestusmärgiga 19. sajandi lõpul Euroopat valitsenud rassismile ja marurahvuslusele, vaid lihtsalt maniakaalsusega" (Hvostov 2004). Ent väljaspool teadust, nt ajakirjanduses, ei peljata Saksa nimetada kõrvuti Ago Künnapi, Kalevi Wiiki, Urmas Sutropi, Lennart Meri jt tunnustatud, kuid peavoolust hälbivate mõtlejatega (vt nt Kangur 2001), mis kinnitab, et tema pseudolingvistilistel ja pseudoajaloolistel teooriatel on eesti kultuuris oma mõjuruum.

Jüri Härmatare teooriat on kritiseerinud Ariste (1980), samuti Jaan Puhvel (1996). Samas on ühes internetifoorumis nimetatud Härmatare teost imeliseks raamatuks, kuna usutakse, et see tõestab, et sumerid rääkisid eesti keeles. Populaarne on ka tema toodud näide ukse käepidemel olevast kirjast Daaravahusa majaukse kaasa käina, kärata, millest üritatakse ikka ja jälle leida kinnitust eestlaste suursugusele päritolule, aga nii intrigeeriv näide võib olla levinud ka Härmatare teosest sõltumatult.

Oskar-Adolf Põldemaa kui lennuka fantaasia, hea fabuleerimisoskuse ja värvika elukäiguga inimene on suutnud kõikvõimalikes situatsioonides ühiskondlikku tähelepanu nautida, olgu siis hullumeelse noorpõlveideega müüa kodutalu elatist võimaldava laeva ostmiseks (Pesti 2009a) või eesrindliku töölisena Nõukogude Liidus. Ent tema keeleteaduslikud vaated ei pälvinud kuigivõrd tähelepanu, poolesajaleheküljelise brošüüri Muinaskiirkiri kõneleb eesti keeles avaldas ta omakirjastusliku väljaandena. Kusjuures see polnud tema kirjastajadebüüt - aasta varem oli trükivalgust näinud paarikümneleheküljeline vihikuke Relvata enesekaitse: võitlussüsteem mõningate valutekitavate enesekaitse võtetega edukaks vastupanuks tugevamale ehk relvastatud vastasele.

Üldsuse mõningase tähelepanu pälvis Põldemaa alles postuumselt, sedagi mitte muinaskiirkirja teooria tõttu, vaid tänu tugeva paigaidentiteediga Saaremaa muuseumi töötaja Olavi Pesti huvile kodusaarel elanud silmatorkava 
isiksuse vastu, mille tulemuseks olid kaks pikemat kirjutist maakonnalehes Oma Saar (Pesti 2009a, 2009b). Põldemaa muinaskiirkirja teooria on liiga raskesti jälgitav, segane ja ilmselt näis ka muidu alternatiivteooriaid pooldavale auditooriumile uskumatu ja vastuvõetamatuna.

\section{Pseudolingvistiliste teooriate tekke põhjusi}

Pseudolingvistika retseptsiooni vaatlus võimaldab sedastada mitmeid huvitavaid nähtusi. Siinkohal jätan kõrvale keeleteadlaste kriitika, millel pole antud kontekstis muud tähendust kui teadaandmine, et vaatlusalused teooriad on lingvistika teaduslikust diskursusest välja arvatud ning kuuluvad seega paraloogia valdkonda. Folklooriuurimise seisukohalt on oluline, milliseid tõekspidamisi ja vaateid selline harrastusteadus kandis ja edastas, millisest sotsiaal-kultuurilisest keskkonnast see võrsus ja milline ideoloogia seda suunas. Kahtlemata on olulised ka kõnealuste teooriate loojate isiksuslikud omadused, kuid see on pigem psühholoogia (võib-olla paiguti koguni psühhiaatria) valdkonda jääv probleem.

Kultuurikeskkond iseenesest ei põhjusta paraloogiliste teooriate teket, kuid kultuurikeskkonnast sõltub, millised need teooriad olla võivad.

Henrik Juhankatti teose ilmumise ajaks 1927. aastal olid ilmunud Karl August Hermanni ja Jüri Truusmanni pseudolingvistilised teooriad, mis olid selleks ajaks juba kõlapinda leidnud ja mõju avaldanud. Juhankatti teooriaga samaaegselt oli oma pseudolingvistilise teooria avaldanud August Laurij (1926), ent ajavahe on liiga väike, et ta oleks saanud Juhankatti teooriat otseselt mõjutada. Need teooriad võisid tekkida paralleelselt. Sel ajal oli Eesti veel noor rahvusriik ja eestlased rahvusena vajasid eneseteadvuse tõstmist. Selline taust tingis asjaolu, et kõik rahvuslik läks hinda ja rahvusromantilist kultuurisuunda toetas valitsus.

Kristi Kuke magistritöös Rahvuse arengu peegeldumine ajalookäsitlustes Eesti näitel on kirjeldatud Eestis kehtinud ajaloomüüte. Eestis oli 19. sajandil arvamus, et eestlased pärinevad Kesk-Aasiast ja on mongolid, seega germaanlastest alamat rassi. Nii leviski Soomest Eestisse soomeugrilaste ja sumerite suguluse idee, mis oli alguse saanud Ungarist 19. sajandi keskpaigas (Kukk 2005).

Pseudolingvistiliste teooriate avaldamist ja levikut eelmise Eesti Vabariigi ajal soodustas ka toonane kirjanduspilt. Siis elas vaikselt edasi 19. sajandi lõpul tekkinud rahvusromantika, mille mõjul ilmus muinasaega kajastavaid ilukirjanduslikke teoseid. Üheks neist oli tänapäevani väärtustatud Mait Met- 
sanurga Ümera jõel (1934), kus kirjanik otsis minevikust võitlevat kangelast, keda tema kaasaja tegelikkus ei pakkunud (Pärsimägi 1981: 359). Teiseks näiteks samast ajastust võib tuua Karl August Hindrey kaheköitelise ajaloolise romaani Urmas ja Merike (1935-1936), mille eest ta pälvis 1937. aastal riigivanema auhinna. Seal üritab autor näidata kogukondliku ülikuteklassi teket eesti hõimude seas I ja II aastatuhande vahetusel, kusjuures ta ühendab muinsuse heroiseerimise psühholoogilise analüüsiga, luues ajaloolises süžees tiheda isikukujutuse. Samas ta ületähtsustab õilsa ülikuvere missiooni, mis kahjustab ajaloolist tõepärasust (Säärits 1995: 119).

Muinaseestlasi heroiseeriv maailmapilt jäi alles ja lausa konserveerus pagulastel, kes lahkusid Eestist Teise maailmasõja päevil. Rahvusromantiline ideaal aitas neil diasporaas elades eestlust säilitada. Esimestel eksiiliaastakümnetel olid pealegi kontaktid Nõukogude Liidu poolt okupeeritud kodu-Eestiga vaid juhuslikud. Hiljem aitas okupatsiooniaegse ideoloogia vastumeelsus säilitada endist rahvusromantilist maailmavaadet.

Pseudolingvistilised teooriad ja rahvusromantika on seotud keele prestiižiga. Eesti keele ja üldse maailma mõistes väiksemate keelte prestiiž on vähemal või rohkemal määral ohustatud. Nii toob János Pusztay välja fakti, et KeskEuroopa riikides on küllaldaselt ametnikke, kes valdavad inglise, prantsuse ja saksa keelt, aga peaaegu ei ole neid, kes oskaksid peale mainitud keelte ja oma emakeele veel mõnda Kesk-Euroopa väiksemat keelt. Pusztay väljendab muret suurte keelte, iseäranis inglise keele domineerimise üle, mis on viinud selleni, et näiteks Ungaris ei ole rahvuskeelsetel publikatsioonidel enam teaduslikku kaalu (Pusztay 2007).

Paul Johansen seletab eestlaste alaväärsustunde teket rõhutud talupojaseisusega teiskeelse aadlivõimu piirkonnas (Johansen 1989: 1502).

Sõnaga, eesti keel polnud veel täieõiguslik kultuurkeel. Üldtunnustatud kõrgema klassi keel oli saksa keel, kuid sakslaste suhtes polnud eestlaskond kuigi sõbralikult meelestatud, seetõttu oli prestiižsem otsida sugulasi vanade kultuurrahvaste hulgast. Pseudoteaduslikud keelesuguluse hüpoteesid otsivad keelesugulusi just prestiižikamate keelte hulgast, mitte nende hulgast, mida mingil põhjusel peetakse madalamaks, vähemarenenuks, vähemkultuurseks. See on alaväärsuskompleksi ilming. Alaväärsuskompleks ei pruugi ilmneda ainult alaväärsuskompleksi põdeva rahva enda esindajate seas, vaid ka selle rahva (või rahvusrühma) imetlejate seas, eesti keelest rääkides seega estofiilide seas, nagu see on täheldatav Gleye puhul.

Valev Uibopuu ütleb: "Suuremate probleemühikute hulgast, mis [---] esiplaanile on kerkinud, tuleb küll igasugu päritolu- ja põlvnemisküsimusi silmapaistvamaiks lugeda. Ei leidu vist palju inimesi, kes ei oleks huvitatud oma 
esivanemaist, sugulussuhteist ja kuuluvusest. Moodsa nimetusega kutsutakse seda juurte otsimiseks." (Uibopuu 1984: 5.)

Mõistagi on üks ahvatlevaid leide, mis filoloogiliselt harimata inimest keelte sugulusele mõtlema paneb, sõnasarnasused. Andrus Saareste teatel on eesti keelest umbes 3600 (60\%) soome-urgi sõnatüve, lisaks veel 360 (6\%) tundmatu päritoluga sõnatüve (mis tõenäoliselt on ka soome-ugri sõnatüved), aga sellele kõigele lisandub 1000 (16,8\%) saksa, 250 (4,1\%) vene, 200 (3,3\%) balti, 120 $(2 \%)$ rootsi, $40(0,7 \%)$ läti ja $30(0,6 \%)$ indo-euroopa laenu (Saareste 1952: 49). Sellele lisaks üksikud juhuslikud kokkulangevused ehk juhuslik häälikuline sarnasus ükskõik milliste keeltega (vt nt hiina keele osas Gao 2005).

Ükski neist eeldustest ega ka kõik need kokku ei põhjusta ebateaduslike teooriate teket, samas ilma eeldusteta, ilma kultuuriruumis levivate ideede ja suundumuste, hinnangute ja teadmisteta on pseudoteaduslike teooriate teke võimatu. Ükski vaadeldav pseudoteaduslik keelesuguluse teooria pole märk vaimuhaigusest. Kõigi vaadeldavate teooriate autorid on saanud oma kutsealal hakkama, neil on olnud ühiskonnas vähem või rohkem autoriteeti, kuid nende vastu on kahtlemata huvi tuntud, kusjuures eelkõige heatahtlikku huvi. Pigem on tegemist kummalise mõttelaadi, valedele faktidele tuginemise või mis iganes muul põhjusel sündinud ideedega. Et kõigil juhtudel annab tunda (filoloogiliste) teadmiste puudumine, on selge, et hüpoteeside loomiseks on kasutatud kultuuriruumis üldlevinud arusaamu.

Et antud juhul on juttu keeleteooriatest eesti keele suguluse kohta, saab siiski kõnelda pseudolingvistiliste teooriate tekkimisest eneseteadvuse tõstmise eesmärgil. Serge Lunin kirjutab veebikeskkonnas European Neighbourhood Journalism Network, et ebateaduslike teooriate loojad ei piira ennast oma $\mathrm{nn}$ alternatiivsel lähenemisel. Nad ise usuvad, et toovad keeleteadusse "midagi uut". See tuleneb uskumusest, et ajalugu ja keeleteadus kannatavad kõike, nagu pabergi, mille peale neist kirjutatakse (Lunin 2009). Pseudolingvistilised teooriad näivad teadusmaailmas loomulikult naeruväärsed, aga ometi on nad populaarsed, sest igasugune sensatsioon tõmbab tähelepanu ja nende teooriate loojad kirjutavad ilma erialase koolituseta inimestele arusaadavamalt kui tõsiteadlased (Lunin 2009).

\section{Kokkuvõtteks}

Kuid tuleme tagasi folkloristika juurde, sest ebateadus kuulub pigem folkloori kui teaduse valdkonda. Soome rahvaluuleuurija Lauri Honko on sõnastanud UNESCO folkloorimääratluse, mille kohaselt folkloori ehk pärimusliku ja rahvapärase kultuuri all mõistetakse "kollektiivi traditsioonipõhjalise loomingu 
kogumit, mida esitab rühm või üksikisik, mis vastab ühiskonna ootustele ning kajastab eriliselt ühiskonna kultuurilist ja sotsiaalset identiteeti. Tema normid ja väärtused levivad edasi suuliselt, jäljendades või mõnel muul viisil" (Honko 1989: 8). Honko käsitlusest nähtub, et keel kuulub folkloori hulka, seega kuuluvad folkloori hulka ka keelega seotud hüpoteesid, sh keelesuguluse hüpoteesid. Juba termin folk linguistics ise räägib selle kasuks, et tegemist on folkloristika ja etnoloogia uurimisainesega.

Austria folklorist Leopold Schmidt (1912-1981) on 1947. aastal kirja pannud rahvaluule definitsiooni, mille kohaselt folkloor on "teadus elu funktsionaalsest ülesehitusest pärimusena edasiantavas vormis" (Schmidt 1982 [1947], tsit Wehse 2006: 132). Võime minna siit edasi ja tuletada, et ebateadus on folkloor, mida loovad inimesed, kelle haridus ja teadmised ei võimalda neil kaasa rääkida teaduslikus diskursuses, kuid kes püüavad oma kogemusi siiski teaduse vormis edastada. Ja nagu käesolev uurimus pseudolingvistika näitel kinnitab, võivad need paraloogilised mõttekäigud olla üldhuvitavad, vaatamata sellele, et nad näivad tõsiteadusliku diskursuse seisukohalt naeruväärsed.

\section{Kirjandus}

Aesti 2007-2008. Para-web > Foorum > Alternatiivajalugu > Iidsed kultuurid (http:// www.para-web.org/viewthread.php?tid=1053\&page $=3-20$. mai 2010).

Aikio, Ante \& Aikio, Aslak 2002. Mikä oli todistettava. Suomalaisten juuret: Aikakauslehti (http://www.kaltio.fi/vanhat/indexbeed.html?383 - 14. mai 2014).

Ariste, Paul 1937. Teaduslik kahjur: Prof. emer. Arthur Gleye. Die Wiedergeburt der westfinnischen Geisteskultur. Vaba Maa, 3. aprill, lk 4.

Ariste, Paul 1940. Ebakeeleteadus. Tarvel, Peeter (peatoim). Eesti Entsüklopeedia: täiendusköide. Tartu: Loodus, lk 209-210.

Ariste, Paul 1980. Ebakeeleteadusest. Sirp ja Vasar, 25. jaanuar, lk 5.

Asher, Roland E. \& Simpson, J. M. Y. (toim) 1994. The Encyclopedia of Language and Linguistics 1-10. Oxford: Pergamon Press.

Brown, Keith (peatoim) 2006. Encyclopedia of Language \& Linguistics 1-14. Amsterdam et al.: Elsevier.

Ehala, Martin 2005. Wiik eurooplaste juurtest. Sirp, 21. oktoober (http://www.sirp.ee/ index.php?option=com_content\&view=article\&id=5717:wiik-eurooplaste-juurtest\&cati $\mathrm{d}=7$ :kirjandus\&Itemid $=9 \&$ issue $=3085-6$. mai 2014).

EKRL 1995 = Kruus, Oskar (koost \& toim). Eesti Kirjarahva leksikon = Estnisches Schriftstellerlexikon. Tallinn: Eesti Raamat.

Erelt, Pekka 1999. Eesti teaduse Toslemid. Eesti Ekspress, 22. juuni. 
Gao, Jingyi 2005. Comparison of Swadesh 100 words in Finnic, Hungarian, Sinic and Tibetan: introduction to Finno-Sinic languages = Swadeshi 100 sõna võrdlus läänemeresoome, ungari, hiina ja tiibeti keeltes: sissejuhatus läänemeresoome-hiina keeltesse. Tallinn: Eesti Keele Sihtasutus.

Gleye, Arthur 1937. Die Wiedergeburt der westfinnischen Geisteskultur: Die Urbewölkerung Europas - westfinnischen (hyperboräischen) Ursprungs; Westfinnische Denkmäler vom hohen Norden bis zum aegyptischen Süden, besonders in Kreta. Tallinn: Tallinna Eesti Kirjastusühisus.

Good, Ron 2009. Why the Study of Pseudoscience Should Be Included in the School Science Curriculum (http://www.nd.edu/ ihpst09/papers/Good\%20MS\%20-\%20Study\%20of\%20 Pseudoscience.doc - 13. mai 2014).

Hall, Robert A. 1987. Linguistics and Pseudo-linguistics: Selected Essays, 1965-1985. Amsterdam Studies in the Theory and History of Linguistic Science. Series 4. Current Issues on Linguistic Theory 55. Amsterdam \& Philadelphia: Benjamin.

Honko, Lauri 1989. The Final Text of the Recommendation for the Safeguarding of Folklore. NIF Newsletter 2-3, lk 3-12.

Honko, Lauri 1998. Folklooriprotsess. Mäetagused: Hüperajakiri 6, lk 56-84 (doi: 10.7592/MT1998.06.honko).

Hvostov, Andrei 2004. Edgar V. Saks. "Eesti viikingid”. Eesti Ekspress, 19. veebruar, B8. Härmatare, Jüri 1976. Sumeri kilde. Toronto: [s.n.].

L-E 1928 = Imeleidurid Tõrvas. Patent iseliikuja masina pääle võetud. Lõuna-Eesti 81, 22. september, $1 \mathrm{k} 1$.

Ivanov, Vjatšeslav 1994. Pseudolinguistics. Asher, Roland E. \& Simpson, J. M. Y. (toim). The Encyclopedia of Language and Linguistics 6. Oxford: Pergamon Press, lk 3390-3392.

Jackendoff, Ray 2003. The Structure of Language: Why It Matters to Education. Talk for conference on Learning and the Brain, Cambridge, November 5-8. (library.ibp.ac.cn/html/ cogsci/tclb-2003-1.pdf - 7. mai 2014). Johansen, Paul 1989. Rahvuslik alaväärsustunne ja eelarvamus sotsiaalse tegurina keskaegsel Liivimaal. Looming 11, lk 1502-1517.

Juhankatti, Henrik 1927. Inimkonna keelte tekkimine ja arenemine. Tõrva: H. Treufeldt.

Kangur, Paavo 2001. Kes me oleme - idagoodid või soomeugrilased? Eesti Ekspress, 2. august A26-A28 (http://epl.delfi.ee/news/kultuur/ee-kes-me-oleme-idagoodid-voisoomeugrilased.d?id=50890981 - 7. mai 2014).

Kannukene, Katrin 2008. Helme-Tõrva raamatukirjastajad 1918-1940. Lõputöö. Viljandi: Tartu Ülikooli Viljandi Kultuuriakadeemia raamatukogunduse, infoteaduse ja dokumendihalduse osakond (http://dspace.utlib.ee/dspace/bitstream/handle/10062/6564/ Kannukene-2008-VKA-Loputoo.pdf?sequence=1 - 7. mai 2014).

Kukk, Kristi 2005. Rahvuse arengu peegeldumine ajalookäsitlustes Eesti näitel. Magistritöö. Tartu: Tartu Ülikooli filosoofia teaduskond, üldajaloo õppetool (http:// dspace.utlib.ee/dspace/bitstream/handle/10062/947/kukk.pdf?sequence=5 - 7. mai 2014).

Kõiva, Mare \& Kuperjanov, Andres 2005. Sloveenia folkloristika ja etnoloogia 2. Mäetagused: Hüperajakiri 28, lk 199-210 (doi: 10/7592MT2004.28.sloveenia). 
Laakso, Johanna 2000. Keelepuu on keeleajaloo meetodite tulemus. Eesti Päevaleht, 19. jaanuar (http://epl.ekspress.ee/artikkel/61802 - 7. mai 2014).

Laurij, August 1926. Eestlased. Inimsoo ürgisad ja ürgaja keel. Keele wõti. Pärnu: A. Laurij (Pärnu: A. Jansen).

Libe, Juhan 1928. Ülevaade meie ajalookirjandusest läinud (1927.) aastal. Eesti Kirjandus 5 (www.kirjandusarhiiv.net/?p=121 - 20. november 2014).

Lunin, Serge 2009. Pseudoscience and patriotism. European Neighbourhood Journalism Network, 21. veebruar (http://training.journalismnetwork.eu/profiles/blogs/pseudoscienceand-patriotism - 10. juuli 2010).

Lõugas, Vello 1997. Nüri kirvega keelepuu kallal. Luup 11 (42), 26. mai, lk 40-42.

Lähteenmäki, Mika 2010. 'Sociology' in Soviet Linguistics of the 1920-30s: Shor, Polivanov and Voloshinov. Brandist, Craig \& Chown, Katya (toim). Politics and Theory of Language in the USSR 1917-1938. ed. London \& New York: Anthem Press, lk 35-52 (doi: 10.7135/UPO9780857289483.003).

Martin, Michael 1994. Pseudoscience, the paranormal, and science education. Science \& Education 3 (4), lk 357-371.

Niedzielski, Nancy A. \& Preston, Dennis Richard 2003. Folk Linguistics. Mouton Textbook. Berlin: Mouton de Gruyter.

Oja, Arno 1995. Saks, Edgar Valter. Kruus, Oskar (koost \& toim). Eesti Kirjarahva leksikon = Estnisches Schriftstellerlexikon . Tallinn: Eesti Raamat, lk 502-503.

Pesti, Olavi 2009a. Oskar Põldemaa viis elu. Oma Saar, 11. aprill (http://www.saartehaal. ee/2009/04/11/oskar-poldemaa-viis-elu/ - 7. mai 2014).

Pesti, Olavi 2009b. Oskar Põldemaa viis elu (2). Oma Saar, 18. aprill (http://www. saartehaal.ee/2009/04/18/oskar-poldemaa-viis-elu-2/ - 7. mai 2014).

Postal, Paul M. 2004. Skeptical Linguistic Essays. New York: Oxford University Press.

Puhvel, Jaan 1996. Hitiidid eesti pseudoteaduses ja üldisemalt. Rein Sepa 75. sünniaastapäevale pühendatud konverentsi ettekandematerjalid: Kevad 1996 (http:// my.tele2.ee/rein_sepp/puhvel.htm - 7. mai 2014).

Pusztay, János 2007. Keel, oskused, suveräänsus. Sirp 12 (3152), 23. märts (http:// www.sirp.ee/s1-artiklid/c9-sotsiaalia/keel-oskused-suver-nsus/ - 17. november 2014).

Põldemaa, Oskar-Adolf 1995. Muinaskiirkiri kõneleb eesti keeles: [Eestlaste vanast kirjast]. [Saaremaa]: O.-A. Põldemaa.

Pärsimägi, Aino 1981. Mait Metsanurk. Eesti kirjanduse ajalugu IV. Tallinn: Eesti Raamat, lk 343-368.

Saareste, Andrus 1952. Kaunis emakeel. Lund: Eesti Kirjanike Kooperatiiv.

Saari, Peeter 2008. Libateaduse anatoomiast ja taksonoomiast. Akadeemia 10, lk 22252239 (http://www.fyysika.ee/teadus/libateaduse_anatoomiast/ - 7. mai 2014).

Saks, Edgar Valter 1966. Esto-Europa: A Treatise On The Finno-Ugric Primary Civilization in Europe: Studies in Ur-European history II. Montreal \& Lund: Võitleja. 
Säärits, Ello 1995. Hindrey, Karl August. Kruus, Oskar (koost \& toim). Eesti Kirjarahva leksikon = Estnisches Schriftstellerlexikon . Tallinn: Eesti Raamat, lk 118-119.

Uibopuu, Valev 1984. Meie ja meie hõimud. Peatükke soomeugrilaste minevikust ja olevikust. Lund: Eesti Kirjanike Kooperatiiv.

Ultra, J. 1928. Ülihuvitav raamat. Väga huvitavad väited H. Treufeldt'ilt. Lõuna-Eesti, 14. jaanuar, lk 4.

Villandi, Maarja 2010. Ebateaduslikud teooriad ja alternatiivsed teaduslikud teooriad eesti keele suguluse kohta. Magistritöö. Tartu: Tartu Ülikooli filosoofiateaduskonna eesti ja soome-ugri keeleteaduse osakond (http://dspace.utlib.ee/dspace/bitstream/ handle/10062/15131/villandi_maarja_MA.pdf?sequence=1 - 7. mai 2014).

Wehse, Rainer 2006. "Kõik saab alguse tekstist!" Kas pöörduda tagasi klassikalise kaanoni juurde?. Mäetagused: Hüperajakiri 33, lk 131-140 (doi: 10.7592/MT2006.33. wehse).

\title{
Summary
}

\section{Pseudo-Linguistics as a Folklore Phenomenon}

\section{Maarja Villandi}

Keywords: folklore, paralogical form, popular linguistics, pseudo-linguistics

\begin{abstract}
The article discusses pseudo-linguistic theories about the kinship of the Estonian language published since the 1920 s. The author describes these theories, pointing to their characteristic features and causes of origin, and then proceeds to give an overview of the non-scientific theories of the kinship of the Estonian language devised by Henrik Juhankatti, Arthur Gleye, Edgar Valter Saks, Jüri Härmatare and OskarAdolf Põldemaa. All the authors, none of whom are linguists, attach great importance to the Estonian language (resp. Baltic-Finnic languages) in the past, about which there are no corresponding data. They also connect the Estonian language (resp. Baltic-Finnic languages) to the old languages of culture (e.g. Etruscan). These theories have deserved much criticism and they have even been regarded as adverse. The author reaches the conclusion that pseudo-linguistic theories are not necessarily detrimental, but should rather be treated as folkloric manifestations deserving to be studied.
\end{abstract}

